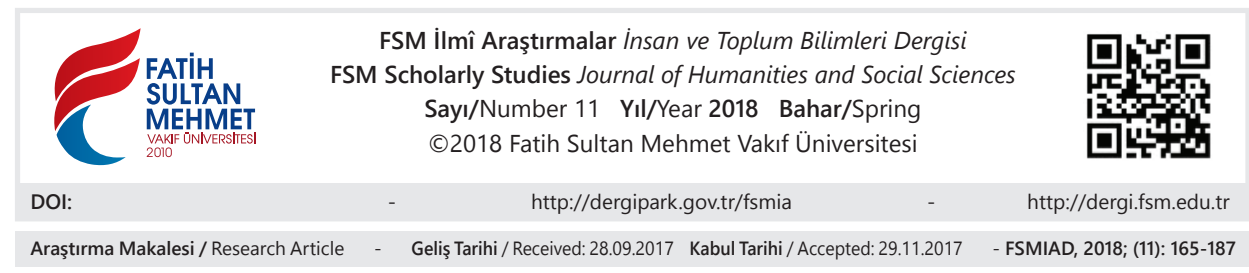

\title{
Değer-Tarafsız Sosyoloji Anlayışına Eleştirel Bir Yaklaşım Zeynep Türkkan*
}

\section{$\ddot{O} z$}

Bu makalede, Aydınlanma Dönemi bilim anlayışının bir yansıması olarak ortaya çıkan ve hemen bütün sosyoloji otoriteleri tarafından ortaklaşa benimsenen değer-tarafsız sosyoloji anlayışı çeşitli açılardan sorgulanmaktadır. Bu bağlamda, çalışmada öncelikle değer-tarafsızlığ 1 kavramından ne anlaşıldığ 1 ve onun sosyolojide neden bu kadar önemli görüldüğü üzerinde durulmuş, daha sonra bu kavrama yöneltilen bazı eleştiriler ele alınmış ve sonuç bölümünde de konuya ilişkin görüş ve öneriler dile getirilmiştir.

Anahtar Kelimeler: Değer-tarafsız sosyoloji, nesnellik, bilim.

\section{A Critical Approach to the Understanding of Value-Free Sociology}

\section{Abstract}

In this article, the understanding of value-free sociology which is emerged as a reflection of scientific approach of Enlightenment and adopted by almost all of the authorities of sociology is queried from different perspectives. In this context, in the study, firstly we dwelled on what is understood by the concept of value-free and why it is regarded so important in sociology, afterwards we dealt some critics about conception and in the last part of the study we uttered our views and suggestions concerning to the subject.

Keywords: Value-free sociology, objectivity, science.

* Dr., Süleyman Demirel Üniversitesi İlahiyat Fakültesi Din Sosyolojisi Anabilim Dalı, Isparta/ Türkiye, zeynepturkkan@sdu.edu.tr, orcid.org/0000-0002-7142-0868 


\section{Giriş}

Öznellik ve nesnellik ayrımı, bir taraftan, Aydınlanma Dönemi bilim anlay1şının temel dayanağı olan doğa bilimleriyle yakından ilişkiliyken diğer taraftan, birtakım toplumsal ve ideolojik temellerin üzerinde yükselen bir olgudur. ${ }^{1}$ Aklın ve bilimin karakterize ettiği Aydınlanma Dönemi bilim anlayışına göre bilim, sadece olgularla ilgilenir ve değer yönünden nötr ve tarafsız bir faaliyettir. ${ }^{2} \mathrm{Bu}$ bağlamda, örneğin modern bilimin teorik temellerinin oluşumunda etkin bilimcilerden Bacon, bilginin ilerlemesinin, önyargıların, zihinsel kurguların ve inançların işin içine katılmadan deney ve gözleme dayandırılması yoluyla gerçekleşebileceğini savunmuştur. Başka bir Aydınlanma filozofu olan Descartes ise kartezyen düalizm ile nesnel olgu/fiziksel gerçeklik dünyası ve öznel bilinç/değerler dünyasını birbirinden kesin bir şekilde ayırmıştır. ${ }^{3}$

18. Yüzyılın devrimci burjuvazisi, Hıristiyanlığın Tanrı-kul ilişkisini düzenleyen ideolojisini reddetmiş, ve doğanın ve aklın çizdiğinin dışında hiçbir sınırlandırmayı kabul etmemiştir. İnsanların eşit haklara sahip olduğu fikri (doğal hak, insan hakları vb.) bu yaklaşımın ürünüdür. Hıristiyanlığın dini ideolojisine karşı 'akıl' ve 'doğa'nın mücadelesini veren burjuvazi, toplumsal gücü ele geçirdiğinde ideolojisini kendi çıkarları doğrultusunda kullanmıştır. Burjuvazi açısından, insanların -nesne (doğa ve akıl) karşısında atandıkları yerle ilgili olarak- gerçekten eşit haklara sahip olup olmadıkları değil, eşit haklara sahip olduklarını düşünmeleri önemliydi. Aksi takdirde, ideolojisi, burjuvazinin gücünün aleyhine dönecekti. Böylece öznellik/nesnellik ve akı1/doğa karşıtlıklarının birleşimi burjuvazi ideolojisine iliştirilerek onun çıkarlarının korunmasını sağlar. ${ }^{4}$

Neticede modern bilim, Hıristiyanlığın dünya görüşünün aksini söyleyen bir ideolojiyle birlikte yükselmiş ve güç elde etmiştir. Burada doğanın ve aklın düzeni (dolayısıyla da nesnellik) itaat edilmesi beklenen en yüksek otorite olmuştur. Başka bir anlatımla, burada "soyut Tanrı inancı nesnellikle yer değiştirmiştir. Hıristiyanlığın egemen olduğu toplumda boyun eğilmeye layık olan yegâne otorite Tanrı iken, bilimin egemen olduğu toplumda bu otorite nesnellik olmuştur." 5

1 Robert Franck, "Knowledge and Opinions", Counter-Movements in the Sciences, Ed. By Helga Nowotny- Hilary Rose, D. Reidel Publishing Company, Dordrecht:Holland/ Boston: USA/ London:England, 1979, pp. 39-56.

2 Doğan Özlem, Etik-Ahlak Felsefesi, Say Yayınları, İstanbul, 2010, s. 177.

3 Ömer Demir, Bilim Felsefesi, 3. Bask1, Vadi Yayınları, Ankara, 2007, s. 145.

4 Franck, 1979, s. 46-47.

5 Demir, 2007, s. 146. 
Post-modern dönemde modern bilimin kesinlik ve evrensellik iddialarıyla birlikte nesnellik iddiası da sorgulanmıştır. Fakat yukarıda da belirtildiği gibi modern bilim ideolojisi, yalnızca bilimle değil aynı zamanda egemen toplumsal s1nıfların çıkarlarıyla ilgilidir. Ayrıca söz konusu ideoloji, -özellikle eğitim kurumları olmak üzere- çeşitli toplumsal kurumlar yoluyla da yerini sağlamlaştırmıştır. ${ }^{6}$ Dolayısıyla, bırakın pozitivizmin ortodoks bilim ideolojisi olarak benimsendiği Türkiye' deki $^{7}$ akademik çevrelerde nesnelliğin tahtının sarsılmasını, anti-bilimcilik, anti-pozitivizm gibi türlü eleştirel yaklaşımların ortaya çıktığı Batı'da bile o, tahtını korumaya devam etmektedir.

Bu çalışmada, yukarıda bilimsel ve ideolojik arka planına kısaca değindiğimiz nesnellik prensibinin daha ziyade sosyolojideki yansımalarına odaklanacağız. Nitekim değer tarafsızlığ1 ve nesnellik, kuruluşundan günümüze kadar sosyolojide neredeyse kutsal bir öğreti gibi kabul edilmiş, sosyolojiye giriş̧ kitaplarında ve derslerde sıklıkla "sosyolojinin objektif bir bilim dalı olduğu" vurgulanmıştır. ${ }^{8}$ Bununla beraber gücü, söz konusu öğretinin tahtını sarsmaya yetmese de sosyolojinin bu etik açıdan nötr pozisyonu eleştiren görüşler de ortaya konulmuştur. Aşağıda, akademik çevrelerde bir nevi ideolojik saplantı haline gelen bu anlayışa yöneltilen eleştirilerden bazılarını ele alacağız. Fakat ondan önce değer-tarafsız sosyoloji kavramından ne anlaşıldığı ve kavram üzerindeki ısrarın nedenleri üzerinde duracă̆ız.

\section{Değer-tarafsız Sosyoloji Nedir?}

Değer tarafsızlığı ve objektiflik kavramlarının tanımlarına bakıldığı zaman tanımlarda şu noktaların öne çıktığı görülür: (i) araştırmanın, öznel yargılar (duygu, düşünce, inanç, değer, tercih vb.) karıştırılmadan yürütülmesi, (ii) araştırma sonuçlarının "kişiler arası" bir nitelik taşıması, yani onun başkalarına iletilebilip payla-

6 Wallerstein, tarafsızlık normunun modern bilimin kurumsallaşmasında merkezi bir öneme sahip olduğunu söylemektedir. Bu norm herhangi bir bilim insanı tarafından ihlal edilse bile, normun kendi ihlaline yönelik eğilimleri sınırlandıracak ölçüde güçlü olduğu varsayılır. Bkz. Immanuel Wallerstein, Bilginin Belirsizlikleri, Çev. Berivan Alataş, Sümer Yayıncılık, 2013, s. 17.

7 Hüsamettin Arslan, Epistemik Cemaat, 2. Basım, Paradigma Yayınları, İstanbul, 2007, s. XVI.

8 Örnek olarak bkz. Barlas Tolan, Toplum Bilimlerine Giriş, 3. Baskı, Ankara, Adım Yay., 1991, s. 332-333; Mustafa Erkal, Sosyoloji, Der Yayınları, İstanbul, 2012, s. 6; Hans Freyer, Din Sosyolojisi, Çev. Turgut Kalpsüz, Ankara Üniversitesi Basımevi, Ankara, 1964, s. 29; Ünver Günay, Din Sosyolojisi, 6. Bask1, İnsan Yayınları, İstanbul, 2005, s. 87-88. Orhan Türkdoğan, Çağdaş Türk Sosyolojisi, Turan Yayıncılık, İstanbul, 1995, s. 15-104. (Kaynakların genelinde sosyoloğun incelediği konuya tarafsız ve objektif bir şekilde yaklaşması gerektiği belirtilmekle beraber bunun kolay bir iş olmadığı da vurgulanmıştır). 
şılabilmesi ve onlar tarafından da tekrarlanabilmesi ${ }^{9}$, ve (iii) araştırma sonuçlarının bizden bağımsız olarak var olan dış gerçekliğe uygun olmas $1 .{ }^{10}$ Görüldüğü gibi değer tarafsızlığı, araştırmanın olgu ve kanıtlara dayanmasını, hatta -Durkheimc1 bir yaklaşımla ifade edersek- "olgulardan hareket edilmesini" "11 gerektirir.

Sosyoloji kitaplarında ve sözlüklerde bu ve benzeri şekillerde tanımlanan değer tarafsızlı̆̆ kavramının pratikte ne anlama geldiğinin o kadar da açık olmad1ğını savunan Gouldner'a göre söz konusu kavram, çoğu sosyolog tarafından muteber temelleri ciddi bir şekilde incelenmeksizin ve ne anlama geldiği hakkında net bir fikre sahip olunmaksızın dogmatik olarak benimsenmekte veya ritualistik olarak onaylanmaktadır. ${ }^{12}$ Gouldner, (i) "değer-tarafsızlı̆̆ına inanç, sosyolojinin değerlerden tam olarak bağımsız olduğu, öyle ki bir problemin seçilmesi, çalışı1ması ve rapor edilmesi süreçlerinin bilimsel olmayan bütün varsayımlardan arındırıldığı anlamına mı geliyor?"; (ii) "değer-tarafsız bir sosyoloji, sosyologların teknik yeterlilik alanları dışındaki şeylerle ilgili değer yargısında bulunamayacakları veya bulunmamaları gerektiği anlamına mı geliyor?"; (iii) "değer-tarafsız bir sosyolojiye inanç, sosyologların, çalışmalarının ahlaki imalarına kayıtsız kaldıkları veya kalmaları gerektiği anlamına mı geliyor?" ${ }^{13}$ gibi sorular yöneltmekte ve bu kavramın, aslında anlamı belirsiz ve tartışmaya açık olan bir grup mitinden başka bir şey olmadığını göstermeye çalışmaktadır.

\section{Neden değer-tarafsız sosyoloji?}

Değer-tarafsızlığ 1 ve nesnellik, hem pozitivist hem de yorumlayıc1 sosyoloji geleneğinde önem verilen bir konu olmuştur. Hatta onun söz konusu paradigmaların ortak noktası olduğu ifade edilmiştir. ${ }^{14}$ Pozitivizm açısından ba-

9 Ahmet Cevizci, Felsefe Sözlügü̈, 3. Bask1, İstanbu1, 1999, Paradigma Yayınları, s. 318; Mehmet Ali Kirman, Din Sosyolojisi Terimleri Sözlüğü, 2. Baskı, Rağbet Yayınları, İstanbul, 2011, s. 235-236; Gordon Marshall, Sosyoloji Sözlüğ̈̈, Çevirenler Osman Akınbay \& Derya Kömürcü, Bilim ve Sanat Yayınları, Ankara, 1999, s. 134; Günay, 2005, s. 87.

10 Brian Fay, Çağdaş Sosyal Bilimler Felsefesi, Çev. İsmail Türkmen, 3. Basım, Ayrıntı Yay., İstanbul, 2012, s. 262-263.

11 Emile Durkheim, Sosyolojik Yöntemin Kuralları, Çev. Cenk Saraçoğlu, İstanbul, Bordo Siyah Yayınları, 2010, s. 102-113.

12 Alvin W. Gouldner, “Anti-Minotaur: The Myth of a Value-Free Sociology”, Social Problems, Vol. 9, No. 3 (Winter, 1962), pp. 199-213. İnternet Erişim http://www.jstor.org/stable/799230, 19.7.2017, s. 200.

13 Gouldner, 1962, s. 199-200.

14 Bu konu hakkında bkz. Gülbenikan Komisyonu, Sosyal Bilimleri Açın, 4. Baskı, Çev. Şirin Tekeli, Metis Yayınları, İstanbul, 2003, s. 85; Adil Çiftçi, Nasıl Bir Sosyal Bilim, Kitâbiyât Yayınları, Ankara, 2003, s. 123. 
kıldığında değer-tarafsızlık, temel bir ilkedir ve bilimi bilim kılan başlıca koşuldur. ${ }^{15}$ Örneğin, Auguste Comte'un savunduğu pozitivizme göre, bilim, yalnızca deney yoluyla bilinebilen, gözlenebilir büyüklüklerle ilgilenir. Sosyoloji özelinde ise pozitivist yaklaşım, toplum hakkındaki bilginin, gözlem, karşılaştırma ve deney yoluyla türetilecek kanıtlara dayanması gerektiğini savunur. ${ }^{16}$ Diğer taraftan, yine pozitivist yaklaşımın önemli temsilcilerinden biri sayılan Emile Durkheim'a göre araştırmacı, zihnindeki peşin hükümlerden sıyrılarak olguların kendi tabiatlarına yönelmeli ve olgular arasındaki nesnel bağlantıları keşfetmelidir. ${ }^{17}$ Durkheim, toplumsal olguların şeyler gibi ele alınması gerektiğini söyler. ${ }^{18}$ Toplumsal olguların şeyler gibi ele alınması, yani nesnellik ilkesinin sürdürülebilmesi için araştırmacının toplumsal gerçeklik karşısında tam bir tarafsızlık içinde olması gerekir. Bu, araştırmacının çalıştığı şeyler karşısında "duygusal olarak tarafsız bir tutum" benimsemesi gerektiği anlamına gelir. ${ }^{19}$

Yorumlayıcı sosyoloji söz konusu olduğunda; -meseleye yaklaşım biçimi pozitivizmden farklı olmakla beraber- değer-tarafsızlığının bu gelenekte de önemli bir yer işgal ettiği görülür. Bu gelenekte bir taraftan, araştırmacının değer yarg1larının zorunlu olarak araştırmayı etkilediği ve bütünüyle "nesnel” bir bilimin mümkün olmadığ1 gerçeği kabul edilirken ${ }^{20}$ diğer taraftan, "değer-tarafsızlığı/ objektiflik" hassasiyet gösterilmesi gereken bir ideal olarak araştırmacının önüne konur. Örneğin, yorumlayıcı sosyolojinin kurucusu sayılabilecek olan Max Weber, ${ }^{21}$ bu öğretinin en hararetli savunucularındandır. Hatta Gouldner'a göre, de-

15 Özlem, 2010, s. 194.

16 Anthony Giddens, Sosyoloji, Yayıma Haz. Cemal Güzel, Kırmızı Yayınları, İstanbul, 2012, s. 46.

17 Durkheim, 2010, s. 71-73, 121.

18 Durkheim, 2010, s. 71.

19 Anthony Giddens, Kapitalizm ve Modern Sosyal Teori, Çev. Ümit Tatlıcan, İstanbul, İletişim Yayınlar1, 2009, s. 154.

20 Max Weber, Sosyal Bilimlerin Metodolojisi, Çev. Vefa Saygın Öğütle, İstanbul, Küre Yay., 2012, s. 98-99; Gibson Burrel-Gareth Morgan, Sosiological Paradigms and Organisational Analysis, Ashgate, England, 1979/1992, s. 5; Russel Keat - John Urry, Bilim Olarak Sosyal Teori, Çev. Nilgün Çelebi, Ankara, İmge Kitabevi, 1994, s. 75; Gulbenikan Komisyonu, 2003, s. 86; Çiftçi, 2003, s. 108.

21 Weber, kendisinden önce Droysen ve Dilthey gibi tarih felsefecilerinin ortaya koyduğu yorumlayıcı yöntemi sosyolojiye uygulayan kişi olduğu için böyle ifade ettik. Bkz. Julien Freund, "Max Weber Zamanında Alman Sosyolojisi”, Çev. Kubilay Tuncer, Sosyolojik Çözümlemenin Tarihi, Ed. Tom Bottomore-Robert Nisbet, Yayına Haz. Mete Tunçay - Aydın Uğur, 2. Bask1, İstanbul, Kırmızı Yayınları, 2010, s. 193. Ayrıca yazılarının, modern fenomenoloji türlerinin doğrudan veya dolaylı ilham kaynağı olması da onun hakkındaki bu nitelemeyi doğrulamaktadir. (Bkz. Giddens, 2009, s. 12) 
ğer-tarafsız sosyoloji mitinin yaratıcısı Max Weber'dir. ${ }^{22}$ Weber'in bu konudaki görüşleri biraz karmaşık veya çelişkili görünse de aslında açıktır. Weber, "olan" ile "olması gereken" arasında mantıksal bir ayrım olduğunu düşünür. ${ }^{23}$ "Olan" ve "olması gereken" arasındaki bu uçurum, empirik analizlerden değer yargılarının türetilmesi diye bir şeyi imkânsız kılar. ${ }^{24}$ Weber, bu görüşüyle "bilim" ile "değerler" alanının birbirinden ayrılabileceğine işaret eder. Aslında Weber, değer yargılarının bilimsel çalışmadan tamamen tasfiyesini de savunmaz. Ona göre, yapılması gereken şey araştırmacının değer yargılarını bilimsel çalışmasından ayrı tutması ve değer yargılarını bilimmiş gibi sunmamasıdır. ${ }^{25}$ Yani Weber'in bu iki görüşü, birbiriyle tutarlı bir şekilde, "bilim" ile "değerler" alanının farklı olduğu ve bunların birbirinden ayrı tutulması gerektiğini söyler.

Değer-tarafsız bir sosyoloji üzerindeki bu ısrarın nedenleri neler olabilir?

Akla gelen ilk yanıt, kuşkusuz sosyolojinin ortaya çıktığı dönemdeki bilimsel atmosfer olacaktır. Sosyolojinin ortaya çıktığı 18. yüzyılın sonları ile 19. yüzyılın başlarında hakim olan bilim anlayışı Yeniçağın modern bilim felsefesidir. Aydınlanma Çağı olarak da isimlendirilen bu dönemde, akıl ve bilim (deneysel bilim) ön plandadır. Aydınlanmanın bilim anlayışına göre, bilim sadece olgularla ilgilenir ve değer yönünden nötr ve yansız bir faaliyettir. Bilimsel araştırma ahlaktan, siyasetten, dinden, ideolojiden, dolayısıyla değerlerden bağımsız olarak yürütülür. Bilim yalnızca olguları betimler, açıklar ve öngörüde bulunabilir, kendisi asla değer yarg1s1 veremez ve değer yargisı üretemez. Olgu yargıs1 - değer yargıs1, olan - olması gereken ayrımı yapılmadan bilimsel faaliyetin özerkliği sağlanamaz. ${ }^{26}$ Halbuki İlk ve Ortaçağ filozoflarında genellikle varlık ile değerin özdeşleştirildiği görülür. Platon ve diğer rasyonalist Grek filozoflarının hemen hepsi için "varlık değerle doğmuştur"; yani var olma değerli olmayı bizatihi içerir. Dolayısıyla Yeniçağ felsefesindeki olan - olması gereken, bilgi - değer ayrımları, İlkçağın rasyonalist filozofları için geçerli değildir. ${ }^{27}$

Kendisine bir bilim dalı olarak meşruiyet zemini arayan sosyoloji, doğal olarak döneminin bahsi geçen atmosferinden etkilenmiş ve var olan bilimsel eğilimlere ayak uydurmaya çalışmıştır. Örneğin, ilk sosyolojik çalışmalarda, bu

22 Gouldner, 1962, s. 199.

23 Weber, 2012, s. 25, 84.

24 Henrik Jensen, Weber and Durkheim: A Methodological Comparison, London and New York: Routledge, 2012, s. 39.

25 Weber, 2012, s. 86-87.

26 Özlem, 2010, s. 177.

27 Özlem, 2010, s. 175. 
dönemde ortaya koydukları olağanüstü başarılar sayesinde hakimiyeti ele geçiren doğa bilimlerinin metodolojisinin örnek alındığı, sosyolojinin bir doğa bilimine benzetilmeye çalışıldığı görülür. Bunun gibi, değer tarafsız sosyoloji doktrininin kökenlerinde, Aydınlanma Çağının, "laik bir dünya görüşünü hayatın her alanında tutarlı olarak gerçekleştirmeye çalışan"28 tavrının ve "düşüncenin metafizik ögelerden arındırılarak bilgi işlerinin doğa bilimleri örneğine göre normlaştırılması"29 ilkesine dayanan pozitivist felsefenin yattığını düşünmek mantık dışı olmayacaktır.

Bir diğer yanıt, bilim ile değer alanının birbirine karışması endişesi olabilir. Bu düşünce Weber'in metodolojik yazılarında dile getirilir:

"Bu derginin sayfalarında, bilhassa da yasama tartışmalarında, sosyal bilimin, yani olgulara dönük analizin yanı sıra, sosyal politika, yani ideallerin ifade edilmesi de kaçınılmaz bir biçimde söz konusu olacaktır. Fakat biz asla bu tür tartışmaları "bilim"miş gibi sunma amacında değiliz ve bu ikisinin birbirine karıştırılmasına karşı elimizden geldiğince önlem alacağız. Bu tür tartışmalarda, bilimin artık konuşma zemini yoktur. Dolayısıyla bilimsel özgürlüğün bu tür durumlar açısından ikinci temel buyruğu; bilimsel araştırmacının susmaya, değer biçen ve eyleyen kişinin ise konuşmaya başladığı noktanın tam olarak neresi olduğu hususunda okurlara (ve tekrarlarsak, herkesten önce bizzat kendine!) karş1 daima açık olma zorunluluğudur. Başka bir deyişle, ileri sürülen argümanların tam olarak nerede analitik anlamaya nerede duygulanımlara başvurduğu aşikar kılınmalıdır. Olgulara dönük bilimsel tartışma ile değer biçmenin sürekli birbirine karıştırılmas1, halen, alanımızdaki çalışmaların en yaygın ve de en zararlı özelliklerinden birisidir. Yukarıdaki argümanlar, kişinin kendi ideallerini tartışma içerisinde açıkça sunmasına karşı değil, bu karışıklığa karşı yöneltilmiştir. Ahlaki kayıtsızlık tutumu ile bilimsel "nesnellik" arasında hiçbir bağlantı yoktur." ${ }^{30}$

Görüldüğg̈ gibi Weber, araştırmacının, değer yargılarını bilimsel alana dahil etmemesini, bu ikisini ayrı tutmasını öğütlemektedir; zira ona göre bu ikisinin birbirine karıştırılması zararlıdır. Burada kanımızca Weber, bilimin, kişiler arası ve nesnel, dolayısıyla da "güvenilir" bir alan, değer yargıları alanının ise kişiye özgü ve öznel, dolayısıyla da "güvenilmez" bir alan olduğunu düşünmektedir. Bu iki alanın birbirine karışması durumunda öznel ve güvenilmez bilgiler veya fikir ve kanaatler, güvenilir alan olan bilimin alanına dahil olacak, bu da bilimin güve-

28 Macit Gökberk, Felsefe Tarihi, 15. Basım, Remzi Kitabevi, İstanbul, 2004, s. 291.

29 Hans Freyer, Sosyoloji Kuramları Tarihi, Çev. Tahir Çağatay, Haz. M. Rami Ayas, Ankara, Doğu-Batı Yayınları, 2012, s. 34.

Weber, 2012, s. 86-87. 
nilirlik özelliğinin zarar görmesine yol açacaktır. Veya okuyucu, bilimsel ve güvenilir olduğuna inandığı kaynaklar tarafından -bunlar gerçekte öznel yargılarla karıştırıldığı için- yanıltılacaktır. Böyle bir hassasiyet haklı gibi görünse de okuyucunun neyin bilimsel neyin değer yargısı bildiren ifade olduğunu kendisinin ayırt edebileceği düşünüldüğünde gereksiz bir uğraş gibi görünmektedir. Diğer taraftan, Weber'in araştırmacıdan, değer yargıları hususunda kayıtsızlık veya orta bir yol benimseme gibi davranışlar beklenmediğini, bu tutumlarla bilimsel nesnellik arasında bir bağlantı olmadığını belirtmesi önemlidir. Zira bu, Weber'in nesnellik anlayışının ideolojik bir saplantıdan ziyade araştırmacının, "gerçekliğe sadık kalması" ve en azından bilim söz konusu olduğunda "dürüst" olması gerektiğiyle ilgili olduğunu gösterir. Eğer Weber'in değer tarafsızlığı hususundaki hassasiyetinin sebebi buysa yani, araştırmacının "hakikate sadık kalması" ise bu hassasiyetin son derece haklı ve yerinde olduğu gayet açıktır. Fakat bu noktada da şu sorular akla gelmektedir: Değer yargısında bulunmak hakikati çarpıtmayı gerektirir mi? Ya da tersten sorarsak değer yargısında bulunmamak hakikate sadık kalındığını garanti eder mi? Hakikate sadık kalıp kalmadığını anlamak için araştırmacının, değer yargısında bulunup bulunmadığına değil, verileri olduğu gibi aktarıp aktarmadığına bakmak gerekir diye düşünüyoruz. Ayrıca değer yargısında bulunmak, hakikatin çarpıtılması değil, yorumlanmasıdır. Yorum ise okuyucu tarafından "bu benim yorumumdur" diye açıklama yapılmaya gerek kalmadan da anlaş1labilecek bir şeydir.

Değer-tarafsızlığı öğretisinin sosyal grup çalışmalarında da sıklıkla dile getirildiği görülür. Hatta bu öğretinin haklılığını iddia edenler genellikle bu konuyu gündeme getirirler. Buna göre araştırmacı, incelediği sosyal grubun inanç ve değerlerine objektif bir şekilde yaklaşmalı ve bunlar hakkında olumlu veya olumsuz yargı bildirmemelidir. Araştırmacının görevi, değer ilişkisini incelemektir, değer yargısı koymak değil. ${ }^{31} \mathrm{Bu}$ hassasiyetin sebebi, eğer olumsuz değer yargısında bulunulduğunda araştırmaya konu edilen grup üyelerinin incinmesinden duyulan endişe ise değer tarafsızlığı öğretisi bu sorunu da çözmeyecektir. Zira bir grubu tamamen tarafsiz ve objektif bir tutumla incelemek; o grup hakkında olumlu veya olumsuz her şeyi olduğu gibi ortaya dökmeyi gerektirir ki bu yapıldığında da grup üyeleri incinebilir. Çünkü olumsuz özellikler ortaya konulduğunda yazar "bunlar kötüdür" demese bile okuyucu bunların kötü olduğunu herhalde anlayacaktır. Dolayısıyla olumsuz özellikler ortaya döküldüğünde hiçbir değer yargısı konulmasa bile grup üyeleri muhtemelen incineceklerdir.

31 Weber, 2012, s. 47; Raymond Aron, Sosyolojik Düşüncenin Evreleri, Çev. Korkmaz Alemdar, 8. Baskı, Kırmızı Yayınları, İstanbul, 2010, s. 358-359. 
Son bir yanıt, değer-tarafsızlık öğretisinin dikkate alınmaması durumunda akademik tartışmaların bilimsel düzlemden çıkıp politik veya ideolojik propagandaya dönüşmesinden duyulan endişe olabilir. Örneğin Weber, editörlerinden biri olduğu Archiv für Sozialwissenschaft und Sozialpolitik adlı derginin (Archives for Social Science and Social Welfare) bir siyasi propaganda yeri olmadığını şöyle ifade etmektedir:

"Archiv, en azından niyetleri açısından, genel olarak politikadaki ya da sosyal politikadaki bazı akımlara karşı polemiklerin yürütüldüğü bir yer asla olmamıştır ve asla olmamalıdır; bununla birlikte, genel olarak politikadaki ya da sosyal politikadaki ideaların lehine ya da aleyhine mücadele yürüten bir yer de olmamalıdır." ${ }^{32}$

Bu konuda Durkheim'ın da benzer ifadeleri bulunmaktadır:

“...sosyoloji partizanca mücadelelerin içine sıkıştı̆ı ve halk arasında yapılandan belki daha mantıklı bir şekilde toplumdaki yaygınlaşmış fikirleri işlemekle yetindiği ve sonuç olarak da herhangi bir uzmanlık gerektirmediği müddetçe tutkuları dizginlemeye, önyargılara set çekmeye yetecek kadar yüksek sesle konuşma hakkına sahip olmayacaktır...Bizim yapmamız gereken şey sosyolojiyi böyle bir rol oynayabilecek konuma taşımak olacaktır." ${ }^{33}$

Her iki ifadede de sosyologların, sosyolojiyi siyasi ve ideolojik propaganda alanından ayırmaya ve ona "bilimsel" bir hüviyet kazandırmaya çalıştıkları görülmektedir. İyi niyetli bir çaba olarak görülebilse de bu (bilimsellik utkusu), "değer tarafsızlığı” dogmasının araştırmacılara dikte edilmesi yoluyla ulaşılabilecek bir şey değildir. Zira bilim, dogmatik baskıların altında ezilmiş ve dışarıdan ve içeriden haddi bildirilerek özgüveni yok edilmiş bilim işçileri tarafından ortaya konulan veri toplama işinden daha üstün bir faaliyet olmalıdır. Üstelik söz konusu dogma birçok açıdan sorunludur ve bilime faydadan ziyade zarar vermektedir. Aşağıda bu sorunları biraz daha ayrıntılı olarak ele alacağız.

\section{Değer-Tarafsız Sosyoloji Anlayışına Yöneltilen Bazı Eleştiriler}

Değer-tarafsız sosyoloji anlayışı, sosyal bilim çevrelerinde bir taraftan baskınlığını sürdürürken diğer taraftan birçok sorgulama ve eleştiriye maruz kalmıştır. Bu eleştirilerin büyük çoğunluğu, "tamamıla objektif bir bilimin mümkün olmadığı” görüşüne dayanmaktadır. Bunun yanında, söz konusu anlayışın, araştırmacıya, söylediği her şeyi olgusal verilerle "kanıtlama" zorunluluğu yükleyerek sosyoloji araştırmalarının veri toplamaya indirgenmesine ve sosyoloji disiplininin entelektüel boyutunun giderek ortadan kalkmasına yol açtığı ileri

32 Weber, 2012, s. 87.

33 Durkheim, 2010, s. 264. 
sürülmüştür. Ayrıca görevi, yalnızca gözlem, betimleme, karşılaştırma, açıklama vb. ile sınırlandırıldığında, bilim insanından ahlaki anlamda bir beklentinin olmadığ veya beklenenin "ahlaki kayıtsızlık" tutumu olduğu anlaşılmış ve bunun, gerek "bilim insanının" vizyonu gerekse toplumun ve nesillerin ahlaki ihtiyaç ve gelişimleri açısından uygun olmadığı iddia edilmiştir. Aşağıda, bunlar ile başka bazı eleştirileri beş maddede toplayarak ele alacağız.

\section{Objektif Bir Bilim Mümkün Değildir}

Tamamen objektif bir bilim mümkün değildir çünkü her şeyden önce "bilen"den bağımsız bir "bilgi" yoktur. "Bilgi", nesnelerin "bilen"in zihninde işlenmiş halidir; dolayısıyla, "bilgi"nin oluşum sürecinde "bilen" hep devrededir. "Bilen" ise yalın ve saf bir varlık değil, belli bir toplumsal ve kültürel ortama ait olan ve kendine ait pratik ilgileri, ahlaki ve estetik değerleri olan bir varlıktır. Dolayısıyla, birtakım sosyal ve psikolojik faktörler araştırmacının değer yargılarını etkiler ve bu yargılar da dönüşümlü olarak onun bilimsel çalışmalarını etkiler. ${ }^{34}$

Diğer taraftan araştırmacı, kendi değer yargılarını araştırmasından uzak tutmaya çalışsa bile "araştırma"nın kendisi başlı başına bazı değer yargılarını gerektirir. Araştırmanın vazgeçilmez şartı olan konu ve yöntem seçimi değer yargıları olmaksızın nasıl mümkün olabilir? Araştırmacı, ilkin önem atfettiği çalışılmaya değer gördügü bir konuyu seçer ve konusuyla ilgili sınırlandırmalarda bulunur. Bu bağlamda, örneğin araştırmacının içinde yaşadığı toplumun kültürel hassasiyetlerinin konu seçiminde genellikle etkili olduğu söylenebilir. Araştırmacılar içinde bulundukları kültür tarafından küstah veya belalı olarak algılanabilecek olan çoğu konudan kaçınır ve üzerinde çalıştıkları problemlerin çoğunun durumunu ona göre ayarlamak için güçlü kültür önyargılarına izin verirler. ${ }^{35} \mathrm{Konu}$ seçiminden sonra araştırmacı, problemi en iyi şekilde tanımlamaya, iyi bir hipotez oluşturmaya ve en uygun araçlarla onu test etmeye çalışır. ${ }^{36}$ Araştırmacı bütün bunları yaparken kendi düşüncesine göre en iyi olan yolları "seçer" ve bütün bu seçimler değerlerle ilişkilidir. Araştırmacı verileri değerlendirirken de "anlamlı"

34 Hanson, 1969, s. 81. Hanson bu bağlamda, kanaat ortamı, sosyalleşme, sosyal baskı, meslekî ideoloji şeklinde dört sosyal faktör ile kişilik seçimi, fikrî sabitlik, kişilik dinamikleri şeklinde üç psikolojik faktörden söz etmektedir. Bkz. David J. Hanson, "Values and Social Science", Social Science, Vol. 44, No. 2 (April 1969), pp. 81-87, İnternet Erişim http://www.jstor.org/ stable/41886713, 24.7.2017, s. 82-85.

35 Robert S. Lynd, Knowledge For What, Princeton University Press, New Jersey, 1939/1967, s. 182.

36 Archie J. Bahm, “Science Is Not Value-Free”, Policy Sciences, Vol. 2, No. 4 (Dec., 1971), pp. 391-396, İnternet Erişim http://www.jstor.org/stable/4531452, 22.6.2017, s. 392-394. 
ve "anlamsız" olanları ayırt etmek zorundadır. Böyle bir ayırt etme olmazsa araştırma bir aptalın çakı1 taşı, çöp ve rastgele yüklemeleriyle dolu çantası gibi olur. ${ }^{37}$

Objektif bir bilimin mümkün olmayışının bir diğer sebebi, nesnel bilim anlayışının kendi içinde çelişmesidir. Bu anlayış çelişiktir çünkü bilimsel tutumun kendisi bir tutumdur ve bütün tutumlar kişisel ve özneldir. Objektif olmaya gönüllülük, sübjektif bir gönüllülüktür. Bu sübjektif tutum olmadan nesnellik mümkün değildir. ${ }^{38}$ Dolayısıyla buradan "nesnelliğin" zorunlu olarak "öznel” koşullara bağl1 olduğu sonucu çıkmaktadır ki bu, öğretinin açıkça kendi içinde çeliştiğini gösterir.

\section{Kendisinden Pratik Fayda Beklenen Bilim Tarafsız Olamaz}

Nesnelliği bilimsel bilginin elde edilmesinin başlıca koşulu olarak gören pozitivizm, aynı zamanda, bilimden pratik fayda beklenmesi gerektiğini savunur. Nitekim, Saint-Simon ile başlayıp Comte, Le Play ve Durkheim ile devam eden Fransız sosyoloji geleneğinde politik karışıklık, grup mücadeleleri ve iç çekişmelere karşı sosyolojiyi, koşulları düzeltici ve istikrara kavuşturucu bir bilim haline getirmek ${ }^{39}$ ortak bir hedeftir. Bilimsel bilginin, toplumdaki bireylerin ve grupların davranışlarını kontrol etmek veya düzenlemek için kullanılabileceği anlayışından dolayı bazen "toplumsal mühendislik" olarak adlandırılan pozitivist yaklaşım ${ }^{40}$, sosyoloji-siyaset ilişkisini de beraberinde getirmiştir zira toplumsal reformların gerçekleştirilebilmesi için kurumsal güce ihtiyaç vardır. ${ }^{41} \mathrm{Bu}$ bağlamda, yöneticiler gerçekleştirilecek toplumsal reformlar hususunda "sosyoloji"den yardım almayı umarken, sosyologlar da ürettikleri bilginin toplumsal hayatın

37 Lynd, 1939/1967, s. 183.

38 Bahm, 1971, s. 28.

39 Edward A. Tiryakian, Émile Durkheim, Çev. Ceylan Tokluoğlu, Sosyolojik Çözümlemenin Tarihi, Ed. Tom Bottomore-Robert Nisbet, Yayına Haz. Mete Tunçay, Aydın Uğur, 2. Bask1, İstanbul, Kırmızı Yayınları, 2010, s. 216.

40 Ted Benton-Ian Craib, Sosyal Bilim Felsefesi, Çev. Ümit Tatlıcan-Berivan Binay, 2. Basım, Ankara, Sentez Yayınları, 2012, s. 39.

41 Bu konu hakkında bkz. Benton-Craib, 2012, s. 68-70. Türk sosyolojisinin siyasetle olan yakın ilişsisini de burada zikretmek mümkündür. Nitekim sosyolog Ziya Gökalp ve Prens Sabahattin gibi isimler siyasetle aktif olarak ilgilenmişlerdir. Ayrıca Türkiye Cumhuriyeti'nin kurucusu Mustafa Kemal Atatürk, Yusuf Akçura ve Ziya Gökalp'in görüşlerinden etkilenmiş ve TC'nin kuruluş yıllarında atılan toplumsal ve siyasi adımlarda bu etki kendini göstermiştir. Konuyla ilgili olarak bkz. Faruk Deniz, "İmparatorluktan Ulus Devlete Geçişte Akçura, Gökalp ve Mustafa Kemal'in Yeni Siyaset Arayışları”, DÎVAN İlmî Araştırmalar, sy.21 (2006/2), ss. 35-62, s. 54. İnternet Erişim http://dergipark.gov.tr/divan/issue/25950/273399, 16.8.2017; İlyas Sucu, “Türk Sosyolojisinin Kimliği: Kuruluş Döneminde Türk Sosyolojisinin Karakteristik Özellikleri”, FSM İlmî Araştırmalar Insan ve Toplum Bilimleri Dergisi, Say1 8, Y11 2016/ Güz, ss.259280. İnternet Erişim http://dergi.fsm.edu.tr/index.php/ia/article/view/769/775, 26.9.2017. 
dönüşümündeki somut etkilerini görmek isterler. Peki ama bilimden pratik fayda beklenmesi ve sosyoloji-siyaset ilişkileri değer tarafsızlığ ve nesnellik anlayışıyla çelişmez mi? Bazı siyasi, sosyal, kültürel hedefler doğrultusunda bilim yapmak onun objektifliğini ortadan kaldırmaz mı?

Burada açık bir çelişki görülmektedir. Fakat ne hikmetse bu çelişkili sosyoloji anlayışı, yaygın bir kabulle günümüze kadar gelmiş olup geçerliliğini hala devam ettirmektedir. Nitekim çağdaş sosyal bilimciler de genellikle pratik hayata yönelik belli hedefler doğrultusunda bilim yaparlar. Örneğin, ekonomistler iş koşullarını iyileştirerek, işi daha "etkili" ve "kârlı" hale getirerek, "iş çevresinin genişliğini azaltarak", "fiyatları sabit tutarak" ve "iş sıkıntısını azaltarak" "refahı yükseltmeye" çalışırlar. Politik bilimciler kamu idaresini "geliştirmeye" çalışırlar. Sosyologlar, keza sosyal organizasyonu, kent koşullarını, aileyi vb. "geliştirmeye" çalışırlar. ${ }^{42}$ Araştırmacıların önüne konan bu hedefler kimler tarafından nasıl belirlenmekte ve "ekonomik refah", "sosyal refah" gibi kavramlar neye referansla tanımlanmaktadır? ${ }^{43}$

Weber bu konuda daha tutarlı görünmektedir. Bilim ile değer arasında mantıksal bir ayrım olduğunu, dolayısıyla bilimin değer anlamında bize yol gösterici olamayacağını düşünen Weber, "bilimin, pratik problemlerin çözümü için bilimsel anlamda geçerli bir ilke tesis edemeyeceğini”" ${ }^{4}$ belirtmektedir. Bu yüzden Weber için bilim, pratik bir fayda amacıyla değil, bir görev olarak yap 11 lır. ${ }^{45}$ Böylece Weber, taraftarı olduğu değer-tarafsız sosyoloji anlayışıyla uyumlu bir yaklaşım ortaya koymuş ve bu konuda pozitivistlerden daha tutarlı davranmıştır. Fakat bu yaklaşımın, bilimin ne işe yarayacağına dair soruları ortadan kaldırması ve bilimsel çalışmalar için önemli miktarda bütçeler ayırarak bu alana yatırım yapan yöneticileri ikna etmesi kolay görünmemektedir.

\section{3. Öncü Sosyologlar Değer-Tarafsızlık Anlayışına Bağlılık Konusunda Tutarlı Davranmamışlardır}

Sosyoloji bilimine önemli katkılarda bulunmuş olan sosyologların birçoğunun çalışmasında açık veya zımnî olarak ortaya konulmuş değer yargılarını görmek mümkündür. Çünkü sosyologlar çalışmalarında yalnızca olguların tespitiyle sınırlı kalmamışlar; verilerin yorumlanması, toplumsal sorunlara çözüm

42 Lynd, 1939/1967, s. 183.

43 Bu konu hakkında Bkz. Lynd, 1939/1967, s. 188.

44 Weber, 2012, 83.

45 Dennis Gilbert, "Social Values and Social Science: An Examination of the Methodological Writings of Weber and Durkheim”, Cornell Journal of Social Relations, Volume 11, Number 1, 1976, ss. 23-29, s. 28. 
önerileri sunulması gibi kişisel kanaatlerini de okuyucuyla paylaşmışlardır. Ayrıca, doğrulanması veya yanlışlanması mümkün olmayan oldukça kapsamlı teoriler ortaya koyanların sayısı da az değildir. Örneğin, sosyolojinin kurucularından sayılan Auguste Comte'un ünlü “üç hal kanunu”nu böyledir. Bu teorideki keyfîliği bizzat Durkheim eleştirmektedir. Durkheim, Comte'un söz konusu "üç hal kanunu"nda bu kanuna dair en ufak bir nedensel ilişkiye rastlanmadığını belirtmektedir. Ayrıca Durkheim'a göre Comte, üç hal kanunundaki üçüncü aşamayı son derece keyfî bir biçimde insanlığın nihai aşaması olarak görmüştür. Hâlbuki gelecekte başka bir aşamanın ortaya çıkmayacağını kim garanti edebilir? ${ }^{46}$

Olgulardan hareket eden, tümevarımcı ve nesnel bir bilim anlayışını savunsa da Durkheim'ın da çalışmalarında kendi ilkeleriyle çeliştiğini görmekteyiz. Örneğin, ünlü eserlerinden biri olan İntihar'da Durkheim, kadınlar ve erkekler hakkında -içinde bulunduğu toplumun yaşam biçimi ve değer yargılarından kaynaklandığını düşündügümüz- birtakım ön yargılı genellemeler yapar. Bunlardan birini örnek olarak verecek olursak Durkheim şöyle der:

"Ortak yaşamın dışında erkekten çok yaşadığı için, toplum kadını daha az etkiler. Toplum onun için daha az gereklidir çünkü o toplumsallığı daha az özümsemiştir. O yöne dönük gereksinimi azdır. Olanı da pek fazla zahmete girmeden karşılar. Birkaç dindarlık uygulamasıyla, bakıp besleyeceği birkaç kedi köpekle evde kalmış kız yaşamını doldurur." ${ }^{\prime 7}$

Ayrıca o, İntihar'ın sonunda, kötülük ${ }^{48}$ olarak adlandırdığı intihar olgusuna çare ararken de kendi kişisel görüşlerini, dolayısıyla da değer yargılarını okuyucuyla paylaşmıştır. ${ }^{49}$

Değer-tarafsız sosyoloji anlayışının belki de bir numaralı sorumlusu sayılabilecek olan Max Weber'in çalışmalarının da değerlerden tümüyle azade olmadığı görülmektedir. Mutlak anlamda nesnel bir bilimsel analizin mümkün olmadığını kabul eden Weber, bu imkânsızlığa rağmen yine de araştırmacının değer tarafsız bir tutum içinde araştırmasını yürütmesi ve bilimsel çalışmasına kendi değer yargılarını karıştırmaması gerektiğini savunmaktaydı. Protestan Ahlakı ve Ka-

46 Durkheim Spencer'1 da benzer şekilde eleştirir. Bkz. Durkheim, 2010, s. 223-224.

47 Durkheim, 2013, s. 210. Benzer ifadeler için bkz. Durkheim, 2010, s. 276-284.

48 İngilizce çeviride "kötülük" (evil) olarak yer alırken Türkçe çeviride "hastalık" olarak yer almaktadır. Bkz. Emile Durkheim, Suicide, Tr. John A. Spaulding and George Simpson, Routledge, London and New York, (Taylor \& Francis e-Library), 1897/2005, s. 357; Emile Durkheim, İtihar, Çev. Z. İlkgelen, İstanbul, Pozitif Yayınları, 2013, s. 399. 
pitalizmin Ruhu'na yazdığı önsözde bu görüşünü yineleyen $W_{e b e r}{ }^{50}$, aynı eserin sonunda karşı çıktığ 1 şeyi yapmaktan, yani kapitalizmin geldiği nokta hakkında kendi duygu ve düşüncelerini ifade etmekten kendini alıkoyamamıştır:

“Asketizm dünyayı yeniden kurmayı ve kendi ideallerini dünyada gerçekleştirmeyi üstüne aldıktan sonra, tarihte daha önce hiç görülmediği bir biçimde bu dünyanın malları insanlar üzerinde artan ve nihayet kaçınılmaz bir güç kazanmıştır. Bugün, onun ruhu (asketizmin ruhu) -kimbilir, belki de en sonunda- bu kafesten kaçmıştır. (Şimdi) mekanik temele dayanan muzaffer kapitalizmin artık bu desteğe ihtiyacı yoktur. Güler yüzlü takipçisi aydınlanmanın gül rengi de, en sonunda, sanki soluklaştı ve "meslekî ödev" düşüncesi, bir zamanların dini düşünce içeriğinin bir hayaleti gibi sinsi sinsi yaşamımızda geziniyor. "Mesleki tatmin"in en yüksek ruhsal kültür değerleri ile doğrudan doğruya bağlantısının kurulmadığı yerlerde, -ya da tersine öznel ekonomik bir zorlama olarak hissedilmediği yerlerde- bugün bireyler yorumlamaktan da tümüyle vazgeçmişlerdir. En serbest olduğu bölge olan Amerika Birleşik Devletleri'nde, dini ve ahlaki kılıfından sıyrılmış olan kazanç uğraşısı, bugün ona bir spor karakterini veren yalın dünyevi tutkularla birleşmiştir. Hiç kimse henüz, gelecekte o kafeste kimin yaşayacağını ve bu devasa gelişimin sonunda da tamamen yeni peygamberlerin mi ya da eski düşünce ve ideallerin mi güçlü bir biçimde yeniden doğacağını ya da -bu ikisinden hiçbiri olmayacaksa- bir tür mekanikleşmiş taşlaşma ve bunun yanı sıra kasılmış bir kendini beğenmişliğe mi geçileceğini, henüz bilmiyor. O zaman tabii ki, bu kültür gelişimi içindeki "son insan" için rahatlıkla şöyle denilebilir: Ruh yoksunu uzmanlık insanları, yürek yoksunu zevk insanları: Bu hiçler, kendi kendilerine, daha önce hiç ulaşılmamış bir insanlık düzeyine tırmandıklarını hayal ederler." ${ }^{51}$

$\mathrm{Bu}$ cümlelerin sonunda değer yargısında bulunduğunun farkında olan Weber günah çıkartırcasına şöyle der: "Böylece, bu saf tarihi tartışmanın yüklenmek zorunda olmadığı değer ve inanç yargıları alanına gelmiş oluyoruz." ${ }^{\circ 2}$ Halbuki kendisi o alana halihazırda girmiş bulunmaktadır.

Biz burada bu üç örnekle yetineceğiz fakat söz konusu durumun bu üç sosyologla sınırlı olmadığını belirtmek gerekir. Esasen yukarıda da belirtildiği gibi, sosyoloji alanında önemli kabul edilen çalışmaların hemen hepsinde değer yargılarının açık veya zımnî olarak mevcut olduğu söylenebilir. Örneğin, Karl Marx'ın teorileri ve öngörüleri, Spencer'ın toplum ile biyolojik organizma arasındaki kıyasları, Freud'un cinsel içgüdülerle toplumsal olaylar arasında kurduğu

50 Weber, 2005, s. 25.

51 Weber, 2005, s. 140-141.

52 Weber, 2005, s. 141. 
bağlaşımlar ${ }^{53}$, Cooley'in “ayna benlik”, Mead'in “genelleştirilmiş öteki”, Veblen'in "gösterişçi tüketim" kavramları vb. hemen hepsi de olgusal kanıtların hayal gücüyle buluşması sonucu ortaya çıkmış görünmektedirler. ${ }^{54}$ Değer-tarafsızl1k dogmasına yeteri kadar saygı göstermeyen bu sosyologlar, bugün bile hala sosyolojinin büyükleri arasında sayılmaktadırlar. Buradan anlıyoruz ki başarılı çalışmalar ortaya koymak için gerekli olan koşul, değer tarafsızlık öğretisine katı bir bağl1lık veya bu öğretinin hararetli savunucusu olmak değildir.

\section{Değer-Tarafsızlık Anlayışı Bilimsel Yaratıcılığı Olumsuz Yönde Etki- lemektedir}

Değer-tarafsızlık anlayışı, bilim insanının söz söyleme alanını minimize ederek onu var olan bilim ideolojisinin bir işçisine dönüştürmektedir. Şöyle ki değer yargısı koymaktan men edilen araştırmacı, değer yargısı üretemeyecek ve ister istemez mevcut değer yargılarını benimsemek zorunda kalacaktır. Dahası, araştırmacıya mevcut sistemin profesyonel hizmetçisi olma rolü biçilerek, kendisinden sistemin gönüllü hizmetkarlığını yapması beklenecektir. Böylece araştırmacılar, gerçek manada entelektüel olmayan ve aslında birtakım değerler üzerine kurulu halihazırdaki kuruma hizmet veren işçiler, danışmanlar veya teknikçiler haline gelmektedirler. ${ }^{55}$

Araştırmacıya biçilen bu yeni rol, onun işini kolaylaştırsa da bilimsel verimlilik açısından olumlu değildir. Bu yaklaşım yüzünden entelektüel bir disiplinin eleştirel niteliği kaybolmakta ${ }^{56}$ ve sosyoloji literatürü günün birinde yorumlanmayı bekleyen nicel veriler ve betimlemelerle dolup taşmaktadır. Bilimselliğin derecesi "kanıtlama" ile ölçülürse -ki modern bilim için bu böyledir- en önemsiz bilgiler kanıtlanması en kolay bilgiler olduğundan bu sonuca varmak kaçınılmaz olur. Ondan sonra, "fotoğraf çeke çeke her yer fotoğraf oldu, bu fotoğraflar ne zaman yorumlanacak" ${ }^{n 7}$ diye kendimize sormaya başlarız.

Araştırmacı, kendisini her an suçlamaya ve cezalandırmaya hazır iki kuvvet tarafından aynı yöne itilmektedir: "Olgu toplama ve olanı betimleme görevini

53 Nurettin Şazi Kösemihal, Sosyoloji Tarihi, 10. Basım, İstanbul, Remzi Kitabevi, 2010, s. 116.

54 David J. Gray, "Value-Free Sociology: A Doctrine of Hypocrisy and Irresponsibilty", The Sociological Quarterly, Vol. 9, No. 2 (Spring, 1968), pp. 176-185. İnternet erişim http://www.jstor. org/stable/4105039, 19.7.2017, s. 178.

55 Gray, 1968, s. 184.

56 Gray, 1968, s. 184.

57 Din Sosyolojisi Anabilim Dalı XII. Koordinasyon Toplantısı ve İslam Coğrafyasında Terör, Göç ve Mültecilik Sempozyumu'nda (30 Haziran- 2 Temmuz, Rize) bir hocamız böyle bir ifade kullanmıştı. 
üstlenmiş bilim işçiliği rolünü kabullenme" yönüne. Onu iten kuvvetlerin biri içinde yaşadığ 1 toplumun mevcut koşullarıdır. ${ }^{58}$ Nitekim sosyoloji biliminin konusunu oluşturan toplumsal meseleler, ister istemez toplumdaki bazı kişi veya gruplar hakkında olup, onları doğrudan veya dolaylı olarak ilgilendirmektedir. Bu nedenle araştırmacı, ilgili kesimlerin tepkisinden çekinerek konuyla ilgili en önemli hakikatleri görmezden gelmek ve onun yerine, daha önemsiz olup rahatsız edici olmayan ama aynı zamanda kanıt niteliği taşıyan nicel verileri ön plana çıkarmak zorunda hissedebilir. Bu durum değer tarafsızlık kuralıyla da pekişir zira yukarıda da belirtildiği gibi bu kurala göre bir bilimsel çalışma için en önemli husus "kanıtlama"dır ve nicel veriler de kanıtlama açısından en uygun araçlardır. Böylece bu iki kuvvet yani bir taraftan toplumsal koşulların getirdiği baskılar ile diğer taraftan değer-tarafsılılı ideolojisi, araştırmacıyı kendisine biçilen "bilim işçiliği" rolünü kabullenmeye zorlar. O halde şunu sormak gerekir: "Bilim işçiliğgi" rolünü kabullenen bir sosyal bilimcinin toplumun ve insanlığın sorunları için yaratıcı çözümler üretebilmesi mümkün müdür? Diğer taraftan, çözüm üretilmeden bırakılan sorunlar katlanarak büyüyüp gelecek nesillere miras olarak aktarılmaz mı? Ve, ilmin ve hikmetin ışığıyla aydınlanmayan bir dünyada hakimiyet tümüyle zorbaların eline kalmaz mı?

\section{Ahlaki Kayıtsızlık Tutumu Bilim İnsanı Olma Vizyonuyla Bağdaşma- maktadır}

Bilim insanının yetki ve sorumluluk alanı yalnızca "olgu toplamak", "betimleme yapmak", "eylemin sebeplerini araştırmak" vb. ile sınırlandırılıp değer konularına girmesi yasaklandığında ortaya şöyle bir tablo çıkmaktadır: Toplumbilimciler olarak, "toplama kamplarında herkesin gözü önünde yapılan eylemlerin tamamıla olgusal bir tasvirini yapmaya ve belki yine olgusal olmak üzere söz konusu failleri eyleme iten güdü ve sebeplerin çözümlemesini yapmaya iznimiz vardır, fakat acımasız lafının ağzımızdan çıkmasına iznimiz yoktur." ${ }^{" 59}$ Böylece; bilim insanı, yalnız dışarıdan değil, aynı zamanda içeriden de baskı altına alınmaktadır. Zira dünya üzerinde yaşanan zulüm ve haksızlıklara karşı durmak herkes için zaten zor bir şeyken bu zorluğun yanında bir de "değer tarafsızlık" ide-

58 Bu bağlamda, Wallerstein, tarafsızlık kavramının bilim insanının hiç tereddüt etmeden "dürüstlüğü” seçeceğini varsaydığını fakat gerçek dünyada işlerin böyle yürümediğini, gerçek dünyada, bilim insanlarının birçok baskıya -hükümetlerden, nüfuzlu kurum ya da kişilerden ve meslektaşlardan gelen dış baskılar ile kendi süper egolarından kaynaklanan iç baskılara- maruz kaldıklarını söylemektedir. Bkz. Wallerstein, 2013, s. 18.

59 Leo Strauss, Doğal Hak ve Tarih, Çev. Murat Şen- Petek Onur, Say Yayınları, İstanbul, 2011, s. 75 . 
olojisinin içeriden uyguladığı baskı, bilim insanını sosyal hayatın problemlerine karşı duyarsız ve pasif bir tutum benimsemeye zorlamaktadır.

Duyarlı bir araştırmacı için bir "ayak bağı" ve "sıkıntı” sebebi olan değer-tarafsızlık öğretisi, toplumuna karşı sorumluluk almaktan kaçınarak kişisel dürtülerinin peşinden giden ve ahlaki hassasiyetten uzak olanlar için ise oldukça kullanışl1 bir mazeret tedarikçisidir. ${ }^{60}$ Hâlbuki bir bilim insanı, sorumluluk duygusuna sahipse ancak bir "entelektüel" olabilir. İslami anlayışta da bu böyledir. Nitekim "âlim" bir kişinin sahip olduğu niteliklerin başında "mesuliyet" duygusu gelir. ${ }^{61}$ Aksi halde, bilim ile uğraşan kişiler, var olan bilim ideolojisinin hizmetkârı olan birer "bilim işçisi”"ne dönüşeceklerdir. Diğer taraftan, "bilim işçileri”nin bile hem toplumlarına hem de öğrencilerine karşı belli bir düzeyde ahlaki sorumlulukları vardır ve olmalıdır. Aksi takdirde, Gouldner'ın dediği gibi “eğer bugün sadece öğrencilerimizin teknik yeterlilikleriyle ilgilenir ve onların ahlak duygularına yönelik bütün sorumluluğu reddedersek veya onu eksik bırakırsak o zaman biz, gelecek bir Auchwitz' de ${ }^{62}$ hizmet etmeye istekli, eğitilmiş bir neslin sorumluluğunu kabul etmek zorunda kalabiliriz." ${ }^{63}$ Nitekim hem yapıc1 hem de y1kıc1 potansiyelleri kendi doğasında barındıran bilim ${ }^{64}$ olumlu veya olumsuz kullanımlara müsaittir. Bu nedenle bilim insanları, bilimin üretilmesi kadar onun nasıl kullanılacağ konusunda da sorumluluk almak durumundadırlar.

\section{Sonuç}

Çalışmamız boyunca, değer-tarafsız sosyoloji anlayışının temelinde, Aydınlanma Döneminin hakim bilimsel eğilimleri ile bazı toplumsal ve ideolojik yönelimler olduğunu ve söz konusu anlayışın çeşitli açılardan eleştiriye tabi tutulduğunu gördük. Sonuç bölümü olan bu kısımda konuya ilişkin bazı görüş ve önerilerimizi ifade etmek istiyoruz.

1. Değer tarafsızlığı meselesinin, kutsal bir öğreti veya ideolojik bir saplant1 olmaktan çıkarılarak, salim bir akılla düşünülmesi ve doğru anlaşılması gerekmektedir. Değerlerden hayalet görmüş gibi korkup kaçmak yerine konunun

60 Gouldner, 1962, s. 204.

61 Bu konu hakkında bkz. Zeki Tan, Kur'an'a Göre Toplumun Yapılanmasında İlim ve Âlimin Rolü, Harran Üniversitesi Sosyal Bilimler Enstitüsü, (Yayınlanmamış Doktora Tezi), Şanlı Urfa, 2002, s. 196-198.

62 Auschwitz-Birkenau, Konzentrationslager Auschwitz, Nazi Almanyası tarafından II. Dünya Savaşı döneminde kurulmuş en büyük toplama, zorunlu çalışma ve sistematik katliam kampı. Bkz. https://tr.wikipedia.org/wiki/Auschwitz-Birkenau , 31.7.2017.

63 Gouldner, 1962, s. 212.

64 Gouldner, 1962, s. 212. 
üzerine gidilmeli ve mesele, sakin ve dikkatli bir şekilde aydınlatılmaya çalışılmalıdır. Kanaatimizce, objektiflik diye lanse edilen fakat gerçekte ikiyüzlülük ve sorumsuzluktan başka bir şey olmayan bu doktrin ${ }^{65}$ artık rafa kaldırılmalı ve "hangi değerler bir bilimsel çalışmada nerede ve ne şekilde yer almalıdır" sorusu üzerinde düşünülmelidir. Nitekim "değer” kavramı oldukça genel bir kavramdır ve birbirinden farklı hatta birbirine taban tabana zıt pek çok konuyu içerisinde barındırmaktadır. Din, mezhep, tarikat, cemaat, milliyet, politik tutum, ideoloji vb. değerler alanına girdiği gibi, kültür, gelenek, görenek ve adetler de değerler alanına girer. Diğer taraftan, özgürlük, eşitlik, adalet, iyilik, kötülük gibi konulardaki kişisel yargılar da değerler alanına girmektedir. Yani örneğin, dünyanın herhangi bir yerindeki herhangi bir katliamı lanetlemek de savunmak da bir değer yargısı koymaktır. Dünyada yaşanan zulümlere karşı çıkmak veya onları alkışlamak bir değer yargısı koymaktır. Değer-tarafsızlık öğretisi ile birbirine zıt bu davranışlar "değerler" adı altında aynı düzeye getirilmektedir. Güzel ile çirkin, iyi ile kötü aynı torbaya konularak aynı muameleye tabi tutulmaktadır ki bu bize göre başlı başına bir haksızlıktır.

2. Bilim ve değerin, birisinin nesnel diğerinin öznel olduğu ifade edilerek birbirinden ayrılmaya çalışıldığını gördük. Halbuki insandan bağımsız tamamen nesnel bir hakikat insan için bilinebilir değildir. Her şeyden önce bilgi, süje ile objenin etkileşiminin bir ürünüdür. Daha önce de ifade edildiği gibi, bilgi, dışsal gerçekliğin insan bilincinde şekillenmesi ile oluşur. Biz yaşadığımız müddetçe kendi bilincimizden asla çıkamayacağımız için dış gerçekliğin bizden bağımsız halini de asla bilemeyiz. Dolayısıyla biz insanoğlunun bilebileceği en nesnel hakikat kendi fiillerimiz olabilir. Kendimizinki kadar iyi olmamakla birlikte diğer insanların eylemlerini de bize yakınlıkları ölçüsünde veya kanıtlar üzerinden k1smen bilebiliriz. Bunun haricinde nicel veriler nesnel bilgi sayılabilir belki ( Türkiye'nin nüfusu 2016 yılında 79.814.871 olarak sayılmıştır gibi) fakat sadece nicel bilgileri aktarmak bizim sosyal bilim yapmamız için yeterli değildir. Bir kere, nicel bir verinin bizim açımızdan kayda değer bir anlam ifade etmesi için, onun, toplumdaki veya dünyadaki başka şeylerle ilişkisinin kurulması gerekir. Aksi taktirde, söz konusu nicel veri sadece sınırlı bir bilgi verecek ve bu da bizim için pek fazla bir ehemmiyet taşımayacaktır. Ayrıca, bu tür bilgilere ansiklopedilerden veya günümüzde internet yoluyla kolaylıkla ulaş1labilmektedir. Dolayısıyla sosyal bilimcilerden bundan daha fazlasını yapmaları beklenir. Sosyal bilimci, bir amaç, kuram ve yöntem çerçevesinde belli bir konuya yönelir ve bütün analizi boyunca bu husustaki kendi seçimlerini çalışmasına yansıtır. Sosyal bilimci araş-

65 Gray, 1968, s. 176. 
tırmasına daha çok yoğunlaştıkça ve anlamlı sonuçlara ulaşmaya çalıştıkça araştırma nesnellikten daha çok uzaklaşacaktır. Araştırmac1, "bunlar beni nesnellikten uzaklaştırıyor; ben belli bir kuram ve yönteme göre hareket etmek istemiyorum, benim görevim yalnızca verileri aktarmaktır.” gibi bir şey söyleyemez. Çünkü sadece veri aktararak bilim olmaz. Diğer taraftan hemen belirtelim ki, sadece veri aktararak bilim olmadığı gibi sadece değer yargısı koyarak da bilim olmaz. Yukarıda savunulan görüşlerden, herhangi bir çalışmanın sosyolojik değerinin çalışmada ortaya konan değer yargısıyla ölçülebileceği tarzında bir anlam çıkarılmamalıdır. Çalışmanın başarısı, bize göre, ne değer yargısında bulunulmuş olmasıyla ne de değer yargısından kaçınılmış olmasıyla ilgilidir. Çalışmanın başarısı örneğin, gerçekliğin daha önce fark etmemiş olduğumuz bir boyutunu bize fark ettirmesi veya onun zengin bir hayal gücüyle işlenerek etkileyici bir teori haline getirilmesiyle ilgili olabilir. Ya da örneğin bir saha çalışmasında, araştırmacının ele aldığ kanıtlara dayalı olarak ve makul yorumlarla zenginleştirerek incelemesiyle ilgili olabilir. Fakat söz konusu başarı, değer tarafsızlık öğretisine olan bağlılıkla ilgili olamaz zira bu öğretiye katı bir bağlılık çalışmayı veri toplamaya indirger. Yalnızca verilerin derlendiği bir çalışmanın da sosyolojik bir başarı olduğunu söylemek mümkün değildir.

3. Bilimsel hedef ve sorumluluklar yalnızca sosyolojik başarıya da indirgenmemelidir. Nitekim bir çalışmanın sosyoloji bilimine önemli bir katkı sunması o çalışmanın toplumda olumlu değerleri yükselttiği ve ahlaki hayatımıza iyi yönde katkıda bulunduğu anlamına gelmez. Başarıya fazlaca odaklanarak bilimin ahlaki katkısını geri planda bırakan modern bilim anlayışının eksik ve hatalı olduğunu düşünüyoruz. Bize göre, nitelikli bir çalışma, bilimsel başarının yanında pozitif değerlerle de yüklü olmalıdır. O yüzden de, neye tekabül ettiği belli olmayan "değer-tarafsı" ve "objektif" sosyoloji dogması yerine "hakikate sadakat" ve "adil yaklaşım" vurgusu getirilmesini öneriyoruz. Bir bilim insanından beklenen "tarafsız" olması değil, "hak ve adalet"in tarafında olmasıdır. Ortada bir zulüm varsa, bir yerde masum insanlar, çocuklar katlediliyorsa, bir yerde haklar çiğneniyor ve adaletsizlik yapılıyorsa sosyolog, yalnızca bunları tasvir etmekle yetinmemeli, kendisinin hak ve adaletin yanında yer aldığını ortaya koyabilmelidir.

4. Son olarak, değer-tarafsız sosyoloji anlayışını sorgulayan ve eleştiren yukarıdaki tartışmamızdan, sosyoloğun kendisini bir ahlak otoritesi gibi görüp kendi değer yargılarını başkalarına dikte etmeye çalışabileceği ve kendi değerleri açısından uygun bulmadığı kişilere nefret yağdırabileceği, ya da örneğin saha çalışmalarıyla ilgili olarak araştırmacının incelediği sosyal grup hakkında diledi- 


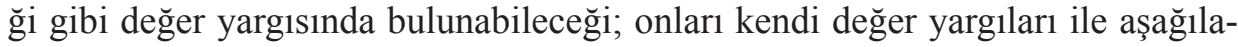
yıp rencide edebileceği tarzında sonuçlar çıkarılmamalıdır. Çok açık bir şekilde ifade edecek olursak biz, olumlu toplumsal ve ahlaki değerlerin artırılmasını ve bu hususta bilimin ve bilim insanının sorumlulukları olduğunu savunmaktayız. Toplumsal, siyasi, ideolojik vb. baskılar bilim insanını yönlendirmemeli; bilakis bilim insanı, toplum ve siyaset için yol gösterici olmalıdır ve bu da "nötr" bir bilim anlayışıyla başarılabilecek bir şey değildir. 


\section{Kaynakça}

Aron, Raymond, Sosyolojik Düşüncenin Evreleri, çev. K. Alemdar, 8. bs., İstanbul, Kırmızı Yayınları, 2010.

Arslan, Hüsamettin, Epistemik Cemaat, 2. bs., İstanbul, Paradigma Yayınları, 2007.

Bahm, Archie J., "Science Is Not Value-Free", Policy Sciences, vol. 2, no. 4, 1971, İnternet Erişim http://www.jstor.org/stable/4531452, 22.6.2017.

Benton, Ted - Craib, Ian, Sosyal Bilim Felsefesi, çev. Ü. Tatlıcan, B. Binay, 2. bs., Ankara, Sentez Yayınları, 2012.

Burrel, Gibson - Morgan, Gareth, Sociological Paradigms and Organisational Analysis, United Kingdom, Ashgate, 1979/1992.

Cevizci, Ahmet, Felsefe Sözlüğ̈̈, 3. bs., İstanbul, Paradigma Yayınları, 1999.

Çiftçi, Adil, Nasıl Bir Sosyal Bilim, Ankara, Kitâbiyât Yayınları, 2003.

Deniz, Faruk, "İmparatorluktan Ulus Devlete Geçişte Akçura, Gökalp ve Mustafa Kemal'in Yeni Siyaset Arayışları”, DÎVAN İlmî Araştırmalar, sayı 21, 2006, İnternet Erişim http://dergipark.gov.tr/divan/issue/25950/273399, 16.8.2017.

Demir, Ömer, Bilim Felsefesi, 3. bs., Ankara, Vadi Yayınları, 2007.

Durkheim, Emile, Suicide, trans. J. A. Spaulding, G. Simpson, London and New York, Routledge, Taylor \& Francis e-Library, 1897/2005. do Siyah Yayınları, 2010.

, Sosyolojik Yöntemin Kuralları, çev. C. Saraçoğlu, İstanbul, Bor, Intihar, çev. Z. İlkgelen, İstanbul, Pozitif Yayınları, 2013.

Erkal, Mustafa, Sosyoloji, İstanbul, Der Yayınları, 2012.

Fay, Brian, Çağdaş Sosyal Bilimler Felsefesi, çev. İ. Türkmen, 3. bs., İstanbul, Ayrıntı Yayınları, 2012.

Franck, Robert, "Knowledge and Opinions", Counter-Movements in the Sciences, ed. Helga Nowotny, Hilary Rose, Dordrecht, Boston, London, D. Reidel Publishing Company, 1979.

Freund, Julien, "Max Weber Zamanında Alman Sosyolojisi", Sosyolojik Çözümlemenin Tarihi, çev. K. Tuncer, ed. T. Bottomore, R. Nisbet, yay. haz. M. Tunçay, A. Uğur, 2. bs., İstanbul, Kırmızı Yayınları, 2010.

Freyer, Hans, Din Sosyolojisi, çev. T. Kalpsüz, Ankara, Ankara Üniversitesi Basımevi, 1964. 
, Sosyoloji Kuramları Tarihi, çev. T. Çağatay, haz. M. R. Ayas, Ankara, Doğu-Batı Yayınları, 2012.

Giddens, Anthony, Kapitalizm ve Modern Sosyal Teori, çev. Ü. Tatlican, İstanbul, İletişim Yayınları, 2009.

, Sosyoloji, yay. haz. C. Güzel, İstanbul, Kırmızı Yayınları, 2012.

Gilbert, Dennis, "Social Values and Social Science: An Examination of the Methodological Writings of Weber and Durkheim", Cornell Journal of Social Relations, vol. 11, no. 1, 1976.

Gouldner, Alvin W., "Anti-Minotaur: The Myth of a Value-Free Sociology", Social Problems, vol. 9, no. 3, Winter 1962, İnternet Erişim http://www.jstor.org/ stable/799230, 19.7.2017.

Gökberk, Macit, Felsefe Tarihi, 15. bs., İstanbul, Remzi Kitabevi, 2004.

Gray, David J., "Value-Free Sociology: A Doctrine of Hypocrisy and Irresponsibilty", The Sociological Quarterly, vol. 9, no. 2, Spring 1968, İnternet erişim http://www.jstor.org/stable/4105039, 19.7.2017.

Gulbenikan Komisyonu, Sosyal Bilimleri Açın, çev. Ş. Tekeli, 4. bs., İstanbul, Metis Yayınları, 2003.

Günay, Ünver, Din Sosyolojisi, 6. bs., İstanbul, İnsan Yayınları, 2005.

Hanson, David J., "Values and Social Science”, Social Science, vol. 44, no. 2, 1969, İnternet Erişim http://www.jstor.org/stable/41886713, 24.7.2017.

Jensen, Henrik, Weber and Durkheim: A Methodological Comparison, London and New York, Routledge, 2012.

Keat, Russel - Urry, John, Bilim Olarak Sosyal Teori, çev. N. Çelebi, Ankara, İmge Kitabevi, 1994.

Kirman, Mehmet Ali, Din Sosyolojisi Terimleri Sözlüğ̈̈, 2. bs., İstanbul, Rağbet Yayınları, 2011.

Kösemihal, Nurettin Şazi, Sosyoloji Tarihi, 10. bs., İstanbul, Remzi Kitabevi, 2010 .

Lynd, Robert S., Knowledge For What, New Jersey, Princeton University Press, 1939/1967.

Marshall, Gordon, Sosyoloji Sözlüğ̈̈, çev. O. Akınbay, D. Kömürcü, Ankara, Bilim ve Sanat Yayınları, 1999.

Özlem, Doğan, Etik - Ahlak Felsefesi, İstanbul, Say Yayınları, 2010. 
Strauss, Leo, Doğal Hak ve Tarih, çev. M. Şen, P. Onur, İstanbul, Say Yayınları, 2011.

Sucu, İlyas, "Türk Sosyolojisinin Kimliği: Kuruluş Döneminde Türk Sosyolojisinin Karakteristik Özellikleri”, FSM İlmi Araştırmalar İnsan ve Toplum Bilimleri Dergisi, Say1 8, Güz 2016, İnternet Erişim http://dergi.fsm.edu.tr/index. php/ia/article/view/769/775, 26.9.2017.

Tan, Zeki, “Kur'an'a Göre Toplumun Yapılanmasında İlim ve Âlimin Rolü”, (Yayınlanmamış Doktora Tezi), Harran Üniversitesi Sosyal Bilimler Enstitüsü, Şanlı Urfa, 2002.

Tiryakian, Edward A., "Émile Durkheim”, Sosyolojik Çözümlemenin Tari$h i$, çev. Ceylan Tokluoğlu, ed. T. Bottomore, R. Nisbet, yay. haz. M. Tunçay, A. Uğur, 2. bs. İstanbul, Kırmızı Yayınları, 2010.

Tolan, Barlas, Toplum Bilimlerine Giriş, 3. bs., Ankara, Adım Yayınları, 1991.

Türkdoğan, Orhan, Çağdaş Türk Sosyolojisi, İstanbul, Turan Yayınc1lık, 1995.

Wallerstein, Immanuel, Bilginin Belirsizlikleri, çev. B. Alataş, İstanbul, Sümer Yayınc1lık, 2013.

Weber, Max, Protestan Ahlakı ve Kapitalizmin Ruhu, çev. Z. Gürata, 4. bs., Ankara, Ayraç Yayınevi, 2005.

Yayınları, 2012.

, Sosyal Bilimlerin Metodolojisi, çev. V. S. Öğütle, İstanbul, Küre

www.wikipedia.org 
